вісник Ужгородського національного університету. Серія : Педагогіка. Соиіальна робота. Ужгород, 2014. Вип. 30. С. 141-144.

3. Самолюк Н., Швець М. Актуальність і проблемність дистанційного навчання. Нова педагогічна думка. Рівне, 2013. № 1.1. С. 193-197.

4. Berrett D. How 'flipping' the classroom can improve the traditional lecture. The Chronicle of Higher Education. Feb. 19, 2012. URL: https:// www.chronicle.com/article/how-flipping-the-classroom-can-improve-thetraditional-lecture/ (дата звернення: 28.01.2021).

5. McLaughlin J.E., Roth M.A., Glatt D.M., Gharkholonarehe N., Davidson C.A., Griffin L., Esserman D.A., Mumper R.J. The flipped classroom: a course redesign to foster learning and engagement in a health professions school. Academic medicine : journal of the Association of American Medical Colleges. 2014. 89 (2). P. 236-243. URL: https://www.semanticscholar.org/paper/The-Flipped-Classroom\%3A-ACourse-Redesign-to-Foster-McLaughlin-Roth/a634dd461038d079a7884139 1a0bdd1cb37c3cc1 (дата звернення: 16.01.2021).

DOI https://doi.org/10.30525/978-9934-26-039-1-92

\title{
ЗАСТОСУВАННЯ УТЕМ-ТЕХНОЛОГІЇ В РАМКАХ КОНЦЕПЦІЇ НОВОЇ УКРАЇНСЬКОЇ ШКОЛИ ДЛЯ УЧНІВ СТАРШИХ КЛАСІВ
}

\author{
Власюк I. В. \\ аспірант кафедри англійської філологї \\ Тернопільського національного педагогічного університету \\ імені Володимира Гнатюка, \\ вчитель англійської та німечької мов \\ Тернопільського навчально-виховного комплексу \\ «Школа-колегіум Патріарха Йосифа Сліпого» \\ Тернопільської міської ради Тернопільської області \\ м. Тернопіль, Украӥна \\ ORCID ID: 0000-0002-6862-697X
}

Постановка проблеми. На сучасному етапі розвитку суспільства 3 великою скорістю відбувається розвиток комп'ютерних технологій та робо-техніки. Такий процес безумовно виступає передумовою формування нової системи освіти. А це відповідно вимагає від держави прийняття нових вимог та формування сприятливого середовища для 138 
розвитку совіти нової ери. Через кілька років найпопулярнішими кар'єрами стануть інженер, програміст, аналітик, робототехніка, IT, технік біологічних та нанотехнології. Ці напрямки навчання включають STEM-освіту, яку можна здобути в початковій школі.

Сьогодні поняття STEM уособлює в собі і науку і математику та інші предмети, це своєрідний новий термін що використовується для поєднання усіх навчальних дисциплін. Сучасна українська школа повинна формувати учнів нового покоління, учнів що здатні легко розбиратися в сучасних технологіях та бути готовими до змін у світі.

Також важливим $€$ виконання наступних завдань 3 боку держави: підготовка вчителів, оновлення матеріалу, а також техніко-педагогічне та методичне забезпечення, організація педагогічного процесу на основі партнерських відносин між вчителями, учнями та батьками.

Цікавим $є$ те, що сьогодні в навчальний процес була введена міжнародна програма «Шість цеглинок» а також Lego. Lego Design розвиває дрібну моторику рук, увагу, пам'ять, критичне мислення, навички спілкування, підвищує мотивацію до навчання, створює просторові ідеї у дітей, здатність працювати в парі в колективі (групі).

Тому на сучасному етапі розвитку суспільства STEAM - це новий, універсальний, орієнтований на практику підхід, за допомогою якого можна долати виклики будь-якої складності. При цьому діти практично реалізують свої знання.

Аналіз останніх джерел та публікацій. Навчальні програми STEM підкреслюють природничо-наукову складову та інноваційні технології. Однак суть цього освітнього напряму полягає у поєднанні міждисциплінарних практик, підходів до вивчення природничих та математичних дисциплін, експериментальної проектної діяльності, інноваційних технологій, художніх дисциплін, лего-дизайну, співпраці та самореалізації. Це свідчить про те, що разом із розвитком науки паралельно повинен відбуватися і розвиток мистецтва.

Таким чином залишається актуальним питання функціонування в Україні STEM-освіти.

Цілі: теоретичний аналіз специфіки застосування STEM-технології в рамках концепції нової Української школи для учнів старші класів.

Виклад матеріалу дослідження. Перехід до інноваційної освіти на європейському рівні вимагає підготовки нового покоління кваліфікованих робітників, здатних відповідати сучасним умовам соціальної мобільності та засвоювати передові технології. За нинішніх умов в Україні користуються попитом: IT-спеціалісти, програмісти, інженери, спеціалісти у високотехнологічній галузі, фахівці в галузі біотехнології 
та нанотехнологій. Щоб здобути сучасні професії, необхідна широка підготовка в різних освітніх галузях науки, техніки, технологій та програмування, які охоплюються навчанням STEM.

Головною метою навчання STEM є реалізація державної політики 3 урахуванням нових вимог вітчизняного Закону «Про освіту» 3 метою посилення розвитку науково-технічної спрямованості в педагогічній та методичній діяльності на всіх освітніх рівнях. Створення науковометодичної бази для підвищення творчого потенціалу молоді та професійної компетентності науково-освітніх кадрів [4].

Для того, щоб підготувати підростаюче покоління до життя у висококонкурентному, високотехнологічному світі, слід розвивати інтерес до науково-технічної творчості, технологій та високих технологій. У багатьох промислово розвинених країнах світу навчання STEM стає все більш популярним як інтерфейс між наукою, технологією, технікою та математикою (математикою). Зараз, можливо, як ніколи раніше, освіта повинна перевершити очікування та вгадати тенденції розвитку суспільства в майбутньому. Інноваційна система науково-технічного навчання STEM набирає популярності у всьому світі.

Діти вчаться вирішувати проблеми, стають новаторами, винахідниками, розвивають логічне мислення та технічну компетентність. Навчальний процес має на меті допомогти учасникам освітнього процесу набути навичок 21 століття: колективної роботи, спілкування, управління проектами, мозкового штурму. Навчання MINT визначає стратегічний розвиток. Навчання STEM зміцнить і вирішить найактуальніші проблеми майбутнього. Навчальна програма STEM базується на ідеї навчання учнів 3 міждисциплінарним та прикладним підходом. Замість вивчення кожної дисципліни окремо, STEM інтегрує їх в єдиний навчальний шлях $[3$, c. 55$]$.

Надання робочих місць досвідченим спеціалістам можливе за умови створення в постаршій школі високоякісної системи освіти. Адже саме тут формуються основні навички учнів, якими вони користуватимуться та вдосконалюватимуться у середніх та старших класах.

До ключових компетенцій Нової української школи належать: спілкування національною мовою (i, якщо потрібно, рідною мовою), спілкування іноземними мовами, математична компетентність, основні компетенції в галузі науки і техніки, інформаційні та цифрові технології життєздатність компетентності, ініціативність та підприємливість, соціальна та громадянська компетентність, обізнаність та самовираження в галузі культури, екологічна компетентність та здорове життя [5]. 
Впровадження принципів STEM-освіти в навчальний процес Нової української школи допоможе максимально реалізувати та успішно засвоїти ці компетенції. Інтеграція та експериментальна проектна діяльність є керівними принципами STEM-освіти, переплітаючись із визначними пам'ятками Нуша [1, с. 55].

Наразі в Україні сформована досить цікава система роботи 3 інтелектуально обдарованими дітьми: конкурси, олімпіади, в яких учні добре виступають. Це трикутник, на основі якого мають бути розроблені підходи до впровадження нових принципів у вихованні дитини. Для наукової та методичної підтримки впровадження STEM-освіти $\epsilon$ особливо важливим розробити інтегровані навчальні програми для спеціальних курсів, факультативів, гуртків з робототехніки, техніки та новітніх технологій для всіх типів навчальних закладі [5].

Програма STEM розглядається як така, що відповідає основним критеріям: актуальність та інноваційність змісту; ясність процесу впровадження; інноваційне мислення викладачів та студентів. Залежно від періоду впровадження, програми STEM можуть: бути короткотерміновими (для літніх шкіл, курсів тощо); середньостроковими (щорічно); тривалими, безперервне навчання. Програми STEM розробляються за такими основними напрямками: інтегровані, міждисциплінарні навчальні програми; робототехніка та технічний розвиток; моделювання літаків; 3D-моделювання; винахідництво; хімічні технології тощо.

Якість навчання значною мірою визначається компетентністю та професійною діяльністю вчителя. Знання - не єдина міра професіоналізму людини у 21 столітті [2, с. 14].

Креативне, аналітичне, креативне, інноваційне мислення, вміння працювати над проектами в команді, інформаційна грамотність та навички ефективного використання IКТ - це неповний перелік характеристик сучасної успішної людини. Завдяки навчанню STEM можна досягти перелічених очікуваних результатів.

Висновки. Таким чином вітчизняна освіта безумовно повинна йти в ногу з часом, школи повинні відповідати вимогам сучасного суспільства та здійснювати підготовку досвідченої молоді. Впровадження освітніх принципів STEM у навчальний простір Нової української школи сприяє створенню принципово нової моделі навчання з новими можливостями для вчителів та учнів. Завдяки міждисциплінарному підходу, інтеграції шкільних предметів, практичній спрямованості, експериментальній та проектній діяльності під час занять, зосередившись у своій діяльності на концепціях Нуша та STEM, ми зможемо досягти сучасного, економічно стабільного максимуму для побудови розумного і щасливрнр суспільства. 


\title{
Література:
}

1. STЕМ-освіта як перспективна форма інноваційної освіти в Україні Матеріали обласної науково-практичної інтернет-конференції. / Авторупорядник Ю. М. Зоря. - Черкаси: ЧОІПОПП, 2018. - 117 с.

2. Іванюк Т. STEM як освітній ресурс XXI століття. STEM-освіта та шляхи iї впровадження в навчально-виховний процес. Тернопіль, 2017.- C. 14-18.

3. Кириленко С., Кіян О. Проблема підготовки вчителя у системі STEM-освіти: розвиток та формування його професійної компетентності. STEM-освіта: стан впровадження та перспективи розвитку: матеріали III Міжнародної науково-практичної конференції, 9-10 листопада 2017 р., м. Київ. Київ: ДНУ «Інститут модернізації змісту освіти», 2017. - 160 с.

4. Концепція «Нова українська школа». Інформаційний збірник $\mathrm{MOH}$ України. // [Електронний ресурс]. - Режим доступу: http://mon.gov. ua.

5. Ночевчук М. Впровадження елементів STEM-освіти у навчання матемапики та фізики // [Електронний ресурс]. - Режим доступу: https://vseosvita.ua/library/statta-na-temu-vprovadzenna-elementiv-stemosviti-u-navcanna-matematiki-ta-fiziki-84380.html.

DOI https://doi.org/10.30525/978-9934-26-039-1-93

\section{INNOVATIVE METHODS OF TEACHING FOREIGN LANGUAGES MODERN LOOK}

\author{
Koliesnikov R. O. \\ Teacher of the English Language \\ Municipal Establishment «Kharkiv special school No. 7» of the Kharkiv \\ Regional Council, \\ Postgraduate Student \\ Municipal Establishment «Kharkiv Humanitarian-Pedagogical Academy» \\ of the Kharkiv Regional Council \\ Kharkiv, Ukraine
}

The modern educational context is characterized by processes that are associated with a change in ideas about the essence and goals of education, which is rapidly developing missay innovative processes, unification of national educational standards, updating social requirements for the system of training specialists and their readiness for development and training. 